\title{
Kontribusi Tulangan Memanjang Terhadap Kekuatan Geser Pada Penampang Balok Beton
}

\author{
Al Fauzi Afendi, Azwarman*, Ria Zulfiati \\ Teknik Sipil Universitas Batanghari Jambi \\ Correspondence email: warman2789@gmail.com
}

\begin{abstract}
Abstrak. Beton bertulang sebagai elemen balok pada umumnya diberi tulangan memanjang (lentur) dan tulangan sengkang (geser), Tulangan memanjang/longitudinal pada balok yang dipasang searah sumbu batang untuk menahan gaya tarik, karena beton tidak dapat menahan gaya tarik melebihi nilai tertentu tanpa mengalami retak-retak dan Tulangan konvensional dikenal dengan konsep perhitungan tulangan pada bagian sengkang yang digunakan untuk menahan gaya geser. Pengaruh momen lentur terhadap kuat geser, Pada kontrusi balok menerus, maka pada daerah tumpuan interior akan terjadi gaya geser dan momen lentur yang besar. Oleh sebab itu penulis tertarik untuk mengadakan penelitian dengan alasan ingin mengetahui jika meningkatkan rasio tulangan memanjang/longitudinal apakah dapat meningkatkan luas geser penampang atau malah tidak mempengaruhi, dengan adanya kontribusi tulangan memanjang/longitudinal terhadap kekuatan geser pada penampang balok beton.Dengan mencari berapakah jumlah sengkang dan bagaimana pengaruh rasio tulangan memanjang/logitudinal terhadap luas geser penampang balok beton. Penelitian ini menggunakan formula sesuai SNI 2847:2013.Adapun pengumpulan data yang digunakan adalah buku peracangan struktur beton bertulang, buku teori dan desain balok plat beton bertulang. Data akan dianalisa dengan membandingkan gaya geser yang dapat ditahan oleh beton adanya kontribusi tulangan memanjang dan tanpa adanya kontribusi tulangan memanjang. Berdasarkan analisa data yang dilakukan pada balok beton yang ditinjau, diperoleh kesimpulan bahwa dengan adanya kontribusi tulangan memanjang hasil yang didapatkan hampir sama atau sama dengan tanpa adanya kontribusi tulangan memanjang, dimana dengan adanya kontribusi tulangan memanjang didapat sengkang/begel sebanyak 8 buah untuk besi $\varnothing 10$ dan 6 buah untuk besi Ø6, sedangkan perhitungkan tanpa adanya kontribusi tulangan memanjang didapat sengkang/begel yang sama yaitu sebanyak 8 buah besi $\varnothing 10$ dan 6 buah untuk besi $\varnothing 6$. Nilai $\rho$ adalah rasio tulangan memanjang/longitudinal, dengan adanya rasio $\rho$ pada perhitungan penulangan geser tidak begitu mempengaruhi luas geser penampang.
\end{abstract}

Kata Kunci: Kontribusi Tulangan, Kuat Geser, Mutu Beton, Rasio Tulangan

\section{PENDAHULUAN}

Beton bertulang merupakan salah satu material bangunan yang paling banyak digunakan dalam dunia kontruksi.Berbagi macam metode analisa dan perancangan struktur beton bertulang berkembang di beberapa negara. Indonesia sebagai salah satu negara yang juga banyak menggunakan material beton bertulang dalam pembangunan suatu kontruksi juga memiliki tata cara perancangan, yaitu SNI 2847:2013 "Persyaratan Beton Struktural untuk Bangunan Gedung" (yang menggantikan SNI lama yaitu SNI 03-2847-2002). Tata cara analisis dan perencangan yang dianut dalam peraturan SNI 2847:2013 sebagian besar berkiblat kepada American Concrete Institute (ACI).

Beton bertulang sebagai elemen balok pada umumnya diberi tulangan memanjang (lentur) dan tulangan sengkang (geser). Tulangan lentur untuk menahan beban lentur yang terjadi pada balok, sedangkan tulangan geser untuk menahan gaya geser. Balok beton merupakan bagian dari struktur bangunan yang berfungsi untuk menopang lantai di atasnya, balok juga berfungsi sebagai penyalur momen menuju kolom-kolom.

Tulangan memanjang/longitudinal pada balok yang dipasang searah sumbu batang untuk menahan gaya tarik, karena beton tidak dapat menahan gaya tarik melebihi nilai tertentu tanpa mengalami retak-retak dan Tulangan konvensional dikenal dengan konsep perhitungan tulangan pada bagian sengkang yang digunakan untuk menahan gaya geser.

Pengaruh momen lentur terhadap kuat geser, pada suatu balok tertumpu sederhana yang memikul beban merata, maka pada bagian tengah bentang balok akan terjadi momen yang besar dengan gaya geser yang kecil atau bahkan nol, sedangkan bagian dekat tumpuan justru terjadi gaya geser yang besar dan momen lentur yang kecil. Pada kontrusi balok menerus, maka pada daerah tumpuan interior akan terjadi gaya geser dan momen lentur yang besar (Agus Setiawan, 2016).

Berdasarkan uraian diatas maka penulis tertarik untuk mengadakan penelitian dengan alasan ingin mengetahui jika meningkatkan rasio tulangan memanjang/longitudinal apakah dapat meningkatkan luas geser penampang atau malah tidak mempengaruhi, dengan adanya kontribusi tulangan memanjang/longitudinal terhadap kekuatan geser pada penampang balok beton. 


\section{Maksud dan Tujuan Penelitian}

Adapun maksud dari pembuatan penelitian ini untuk memenuhi persyaratan menyelesaikan pendidikan strata I dijurusan Teknik Sipil fakultas Teknik Universitas Batanghari dan untuk mengetahui seberapa besar pemanfaatan tulangan memanjang dalam menyumbangkan kuat geser dari kuat geser yang disumbangkan oleh beton.

Tujuan dari penelitian ini adalah :

1. Menghitung berapa jumlah sengkang pada balok yang ditinjau.

2. Menghitung/menganalisis pengaruh rasio tulangan memanjang/logitudinal terhadap luas geser penampang balok.

\section{Landasan Teori}

\section{Desain Penampang Persegi Bertulang Rangkap}

Suatu balok beton penampang persegi dapat didesain sedemikan rupa sehingga memiliki rasio tulangan sebesar $\rho_{\text {maks }}$. Dengan rasio tulangan sebesar $\rho_{\text {maks }}$ ini, maka dapat dihitung besarnya kuat momen rencana yang dapat dihasilkannya. Apabila momen lentur terfaktor yang bekerja masih lebih besar daripada kuat momen rencana tersebut, sedangkan ukuran tinggi dan lebar balok dibatasi, maka dapat dipasang tulangan tekan. Penjelasan berikut akan menerangkan proses desain balok beton tulangan rangkap.

1. Hitung rasio tulangan seimbang $\left(\rho_{b}\right)$ dan rasio tulangan maksimum $\left(\rho_{\text {maks }}\right)$ dengan menggunakan persamaan :

$$
\begin{aligned}
& \rho_{b}=0,85 \times \beta_{1} \frac{f_{c}}{f_{y}}\left(\frac{600}{600+f_{y}}\right) \\
& \rho_{\text {maks }}=\left(\frac{0,003+f_{y} I E_{s}}{0,009}\right) \rho_{b}
\end{aligned}
$$

Hitung $A_{s \text { maks }}=A_{s 1}=\rho_{\text {maks }} b d$ (luas tulangan tunggal maksimum)

Untuk fy $=400 \mathrm{MPa}$, maka $\rho_{\text {maks }}=0,625 \rho_{b}$. Nilai $\beta_{1}$ dalam persamaan $\rho_{b}$ adalah 0,85 untuk nilai fc kurang atau sama dengan $28 \mathrm{MPa}$, dan berkurang sebesar 0,05 untuk tiap kenaikan mutu beton sebesar $7 \mathrm{MPa}$.

2. Hitung $R_{U \text { maks }}$ menggunakan $\rho_{\text {maks }}(\phi=0,90)$ :

$$
R_{U \text { maks }}=\phi \rho_{\text {maks }} f_{y}\left(1-\frac{\rho_{\text {maks }} f_{y}}{1,7 f_{c}^{\prime}}\right)
$$

3. Hitung kuat momen rencana balok bertulang $\left(M_{u 1}\right)$ menggunakan $\rho_{\text {maks }}$ dan $R_{U \text { maks }}$ :

$$
M_{u 1}=R_{u m a k s} b d^{2}
$$

Jika $M_{u 1}<M_{u}$, maka diperlukan tulangan tekan, dan lanjutkan ke langkah berikutnya.

Jika $M_{u 1}>M_{u}$, maka tidak perlu dipasang tulangan tekan. Gunakan persamaa ini untuk menghitung $\rho$ dan $A_{s}=\rho b d$.

$\rho=\frac{f^{\prime} c}{f_{y}}\left[0,85-\sqrt{(0,85)^{2}-Q}\right]$

4. Hitung $M_{u 2}=M_{u}-M_{u 1}=$ kuat momen rencana yang dipikul oleh tulangan tekan.

5. Hitung $A_{s 2}$ dari hubungan $M_{u 2}=\phi A_{s 2} f y\left(d-d^{\prime}\right)$, dan selanjutnya luas tulangan tarik total $\left(A_{s}\right)$ adalah

$$
A_{s}=A_{s 1}+A_{s 2}
$$

6. Hitung tegangan pada tulangan tekan sebagai berikut :

a. Hitung $f_{s}^{\prime}=600\left(c-d^{\prime}\right) / c \leq f_{y}$

b. Atau nilai $\varepsilon_{s}^{\prime}$ dapat dihitung dari diagram regangan, dan $f_{s}^{\prime}=\varepsilon_{s}^{\prime} E_{s}$. Jika $\varepsilon_{s}^{\prime} \geq \varepsilon_{y}$, maka tulangan tekan sudah leleh $f_{s}^{\prime}=f_{y}$

c. Hitung $A_{s}^{\prime}$ dari $M_{u 2}=\phi A_{s}^{\prime} f_{s}^{\prime}\left(d-d^{\prime}\right)$. Jika $f_{s}^{\prime}=f_{y}$, maka $A_{s}^{\prime}=A_{s 2}$. Jika $f_{s}^{\prime}<f_{y}$, maka $A_{s}^{\prime}>A_{s 2}$ $\operatorname{dan} A_{s}^{\prime}=A_{s 2}\left(\frac{f_{y}}{f_{s}^{\prime}}\right)$

7. Pilih tulangan yang akan digunakan sebagai $A_{s}$ dan $A_{s}^{\prime}$, yang mencakupi untuk lebar balok (b). pada beberapa kasus $A_{s}$ dapat disusun dalam dua baris atau lebih.

8. Hitung tinggi total balok (h) dan periksa bahwa $\rho-\rho^{\prime}\left(\frac{f_{s}^{\prime}}{f_{y}}\right)<\rho_{\text {maks }}$. 
9. Dapat dilakukan pemeriksaan akhir $\left(\phi M_{n}>M_{U}\right)$. Sebagai catatan, dalam langkah 1 nilai rasio tulangan $\rho$ dapat diambil lebih kecil dari $\rho_{\text {maks }}$, misalkan diambil $\rho=0,60 \rho_{b}$ atau $\rho=0,9 \rho_{\text {maks }}$, sehingga tulangan tarik yang pada akhirnya dipakai masih lebih kecil dari batasan $\rho_{\text {maks }}$.

10.Regangan pada tulangan dapat dihitung dengan persamaan :

$\varepsilon_{t}=\frac{d_{t}-c}{c} 0,003 \geq 0,005$

\section{Persyaratan Desain Balok Terhadap Gaya Geser}

Proses desain suatu struktur secara garis besar dilakukan melalui dua tahapan:

1. Menentukan gaya-gaya dalam yang bekerja pada struktur tersebut dengan menggunakan metode-metode analisa struktur yang tepat

2. Menentukan dimensi atau ukuran dari tiap elemen struktur secara ekonomis dengan mempertimbangkan factor keamanan, stabilitas, kemampulayanan, serta fungsi dari struktur tersebut.

Dalam perencanaan tulangan geser terdapat beberapa hal yang disyaratkan dalam peraturan, diantaranya adalah lokasi penampang kritis, luas minimum tulangan geser, jarak maksimum tulangan geser, dan sebagainya. Berikut ini diuraikan satu persatu persyaratan yang harus dipenuhi pada saat melakukan desain tulangan geser.

1. Penampang kritis untuk perhitungan gaya geser terfaktor.

SNI 2847:2013 pasal 11.1.3.1 mengizinkan untuk mengambil penampang kritis guna perhitungan kuat geser nominal pada jarak $d$ dari muka tumpuan.Rekomendasi ini diambil berdasarkan fakta bahwa retak diagonal pertama yang terbentuk terjadi pada tengah bentang balok sejarak $d$ dari tumpuan.

2. Luas minimum tulangan geser

Adanya tulangan geser pada balok beton menahan pertumbuhan retak diagonal. Akibatnya daktilitas balok akan meningkat dan kegagalan struktur secara tiba-tiba dapat dihindarkan. Bila tulangan geser tidak disediakan, balok akan berprilaku getas dan kegagalan akan terjadi tanpa ada tanda-tanda keruntuhan terlebih dahulu. Guna mencegah hal tersebut, SNI 2847:2013 pasal 11.4.6.1 menyebutkan bahwa pada suatu komponen struktur lentur (prategang atau non-prategang), harus disediakan tulangan geser minimum $\left(A_{\min }\right)$ apabila $V_{u}$ melebihi $0,5 \phi V_{c}$

3. Gaya geser maksimum yang dipikul tulangan geser

Guna mencegah terjadinya keruntuhan geser-tekan (hancurnya beton akibat beban geser yang besar dan tegangan tekan pada daerah kritis di atas retak diagonal), SNI 2847:2013 pasal 11.4.7.9 memberikan batasan untuk nilai $V_{s}$, yang tidak boleh diambil melebihi $0,66 \sqrt{f_{c}^{\prime}} b_{w} d$. Jika nilai $V_{s}$ yang terjadi melebihi batasan ini, maka ukuran penampang harus diperbesar.

4. Jarak maksimum tulangan geser

Untuk memastikan bahwa retak diagonal akan memotong paling sedikit satu buah tulangan geser, SNI 2847:2013 Pasal 11.4.5, mensyaratkan bahwa jarak maksimum antar tulangan sengkang vertikal tidak lebih dari $d / 2$, atau 600 mm, asalkan $V_{s} \leq 0,33 \sqrt{f^{v}}{ }_{c} b_{w} d$.

5. Kuat leleh tulangan geser

Pasal 11.4.2 dalam SNI 2847:2013 mensyaratkan bahwa kuat leleh tulangan baja yang digunakan sebagai tulangan geser tidak lebih dari $420 \mathrm{MPa}$, dan tidak lebih dari $550 \mathrm{MPa}$ untuk tulangan geser terbuat dari jarring kawat baja.

6. Pengangkuran sengkang

SNI 2847:2013 pasal 12.13 mensyaratkan bahwa tulangan geser harus diletakkan sedekat mungkin ke permukaan tekan dan tarik sejauh masih diperkenankan oleh syarat selimut beton dan jarak terhadap tulangan lainnya, sebab pada saat beban mendekati ultimit, retak tarik lentur akan masuk cukup dalam kebagaian badan balok.

7. Sengkang pertama di muka tumpuan

SNI 2847:2013 pada pasal 11.1.3.1 menyebutkan bahwa tulangan geser harus disediakan pada daerah antar muka kolom hingga sejarak $d$, pada daerah ini balok didesain terhadap gaya geser $V_{u}$ yang besarnya sama dengan gaya geser yang terjadi pada lokasi penampang kritis. Sedangkan sengkang pertama pada umunya dipasang sejarak s/2 dari muka kolom, dengan $s$ dihutung berdasarkan persamaan $V_{s}$ dan $V_{u}$ adalah gaya geser dengan penampang kritis.

\section{Pengaruh Momen Lentur Terhadap Kuat Geser}

Pada suatu balok tertumpu sederhana yang memikul beban merata, maka pada bagian tengah bentang balok akan terjadi momen yang besar dengan gaya geser kecil atau bahkan nol, sedangkan bagian dekat tumpuan justru 
terjadi gaya geser yang besar dan momen lentur kecil. Pada kontruksi balok menerus, maka pada daerah tumpuan interior akan terjadi gaya geser dan momen lentur yang besar.

Pada lokasi dengan gaya geser dan momen lentur besar, mula-mula akan terjadi retak lentur. Selanjutnya, retakretak dalam arah diagonal akan timbul di atas retak lentur ketika kuat tarik beton terlampaui. Dari sejumlah hasil pengujian, retak diagonal pada daerah dengan gaya geser dan momen lentur besar, terjadi pada saat gaya geser mencapai nilai :

$V_{c r}=0,16 \sqrt{f^{\prime}} b_{w} d$

SNI 2847:2013 Pasal 11.2.2.1 mengadopsi persamaan tersebut untuk menghitung kuat geser nominal yang disumbangkan oleh penampang beton:

$V_{e}=\left(0,16 \lambda \sqrt{f_{c}^{\prime}}+17 \rho_{w} \frac{V_{u} d}{M_{u}}\right) b_{w} d$

Dengan $\rho_{w}=A_{s} /\left(b_{w^{*}} d\right), b_{w}$ adalah lebar badan balok (untuk balok T) atau lebar balok persegi. Sedangkan $V_{u}$ dan $M_{u}$ adalah gaya geser terfaktor. Faktor $\lambda$ diberikan untuk mengakomodasi penggunaan beton ringan. Nilai $\lambda$ dapat diambil sebesar 0,85 untuk beton ringan dan 0,75 untuk beton ringan total. Apabila dilakukan penggantian pasir secara persial maka faktor pengali bisa diperoleh dengan menggunakan interpolasi linier dari kedua harga tersebut. Untuk beton normal, $\lambda$ diambil sama dengan 1,0 .

Nilai $V_{u} d / M_{u}$ dalam persamaan 9 tidak boleh lebih besar dari 1,0. Jika $M_{u}$ terlalu besar, maka suku kedua dalam persamaan tersebut akan mengecil dan $\tau_{c}$ mendekati $0,16 \sqrt{f_{c}^{\prime}}$. Jika $M_{u}$ cukup kecil, maka suku kedua akan membesar dan batas atas $\tau_{\varepsilon}$ ditentukan oleh $0,29 \sqrt{f_{e}^{\prime}}$. Sebagai alternative dari persamaan 9, SNI 2847:2013 Pasal 11.2.1.1 memperbolehkan nilai $V_{\epsilon}$ diambil sebesar :

$V_{c}=0,17 \lambda \sqrt{f_{c}^{\prime}} b_{w} d$

\section{METODE}

Adapun konsep perencanaan dari penelitian ini adalah mendesain atau merencanakan penampang balok beton bertulang. Setelah perencanaan selesai, akan dilanjutkan memperhitungkan penampang balok tersebut terhadap kekutan geser yang disumbangkan oleh beton dengan kontribusi tulangan memanjang.

Sumber: Data Olahan, 2020

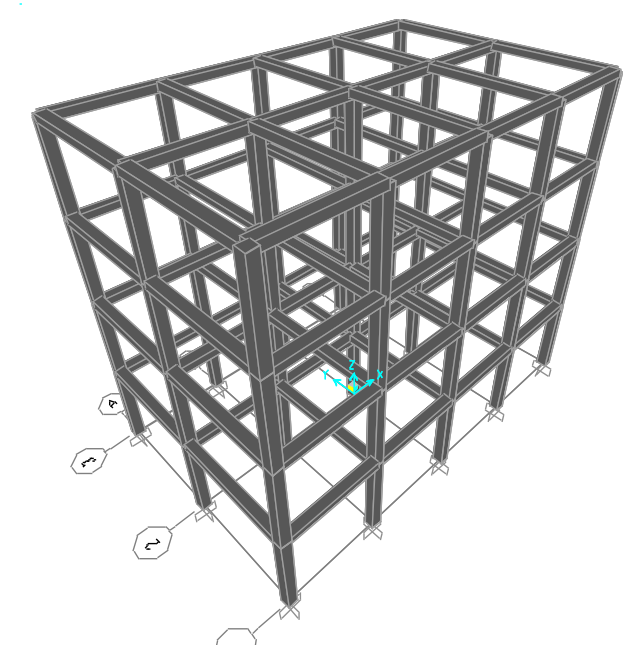

Gambar 1. Rangka Bangunan Lantai 4

Dimana pada gambar rangka bangunan berlantai 4 diatas, untuk penampang balok menggunakan ukran 30x45 $\mathrm{Cm}$, lalu pada penampang kolom menggunakan ukuran $40 \times 40 \mathrm{Cm}$, dengan $f_{\varepsilon} 20 \mathrm{MPa}$ untuk tulangan memanjang 
Al Fauzi Afendi, Azwarman dan Ria Zulfiati, Kontribusi Tulangan Memanjang Terhadap Kekuatan Geser Pada Penampang Balok Beton

dengan mutu $f_{y} 400 \mathrm{MPa}$ dan tulangan geser dengan mutu $f_{y t} 240 \mathrm{MPa}$ untuk keseluruhan. Untuk beban mati (D) terdiri dari berat sendiri pelat lntai 4,48 KNmberat sendiri pelat atap 2,9 $\mathrm{KNm}$ dan beban dinding bata $\frac{1}{2}$ batu 2,4 $\mathrm{KNm}$, untuk beban hidup (L) terdiri dari beban hidup plat lantai sebesar 2,5 $\mathrm{KNmdan}$ plat atap sebesar $1 \mathrm{KNm}$ tertulis di SNI 1727:2013 tentang pembebanan.
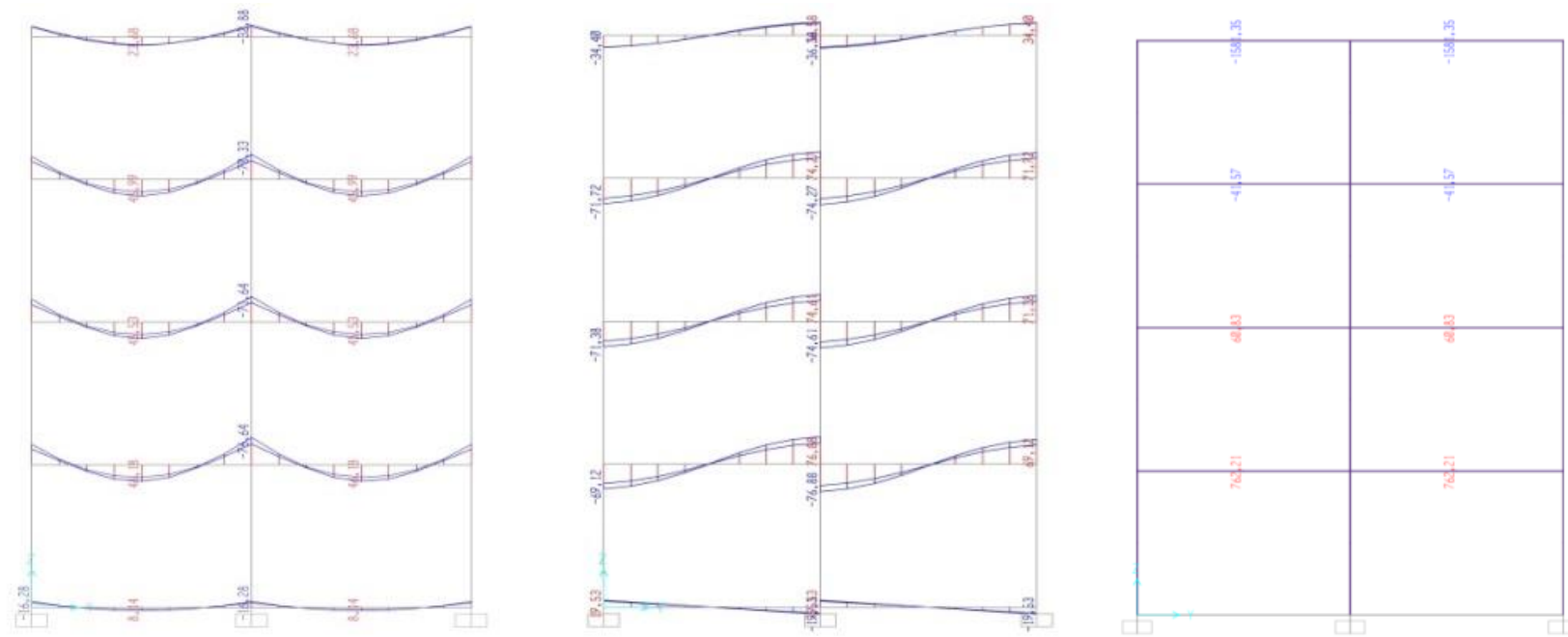

Gambar 2. Gaya Moment, Geser dan Axial Tampak Depan

Sumber: Data Olahan, 2020
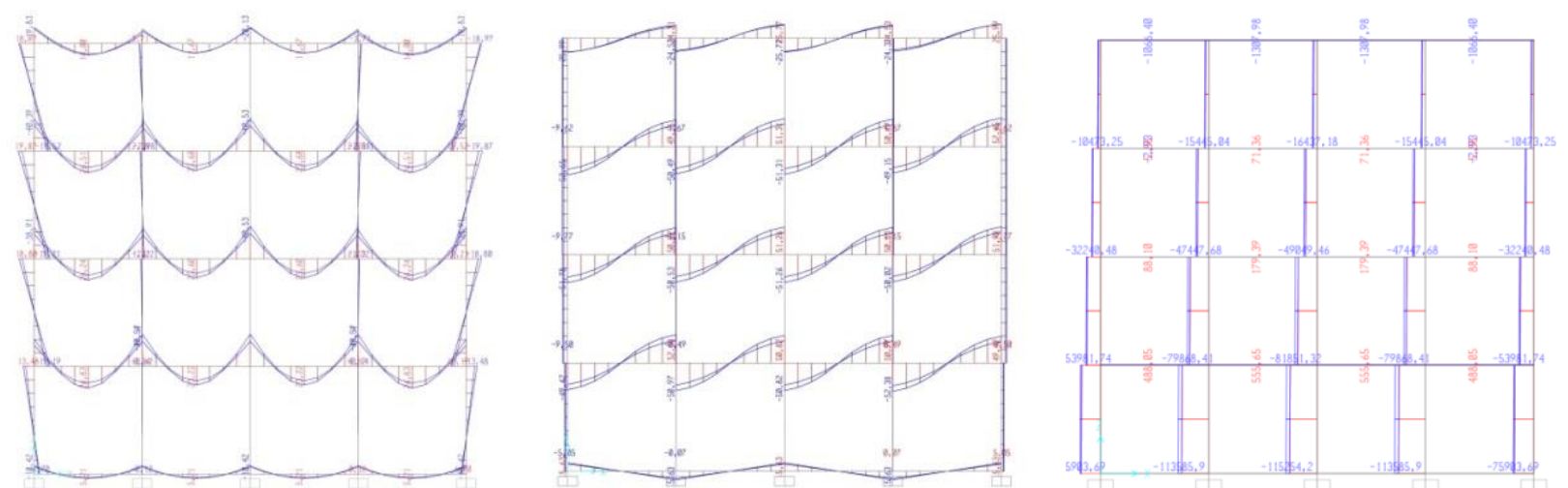

Gambar 3. Gaya Moment, Geser dan Axial Tampak Samping

Sumber: Data Olahan, 2020

Pada hasil gaya moment dan geser diatas didapat nilai terbeser pada gaya-gaya pada rangka bangunan tersebut. Dimana pada balok tersebut didapat moment tumpuan sebesar 76,64 KNm dan momen lapangan sebesar 46,18 KNm, untuk gaya geser sebesar 76, $88 \mathrm{KN}$.

Dari kesimpulan diatas dapat diartikan bahwa pada balok yang mendapat kan gaya moment dan geser paling besar menjadi data primer untuk penelitian kontribusi tulangan memanjang terhadap kekuatan geser pada penampang balok beton. 
Al Fauzi Afendi, Azwarman dan Ria Zulfiati, Kontribusi Tulangan Memanjang Terhadap Kekuatan Geser Pada Penampang Balok Beton

Sumber: Data Olahan, 2020

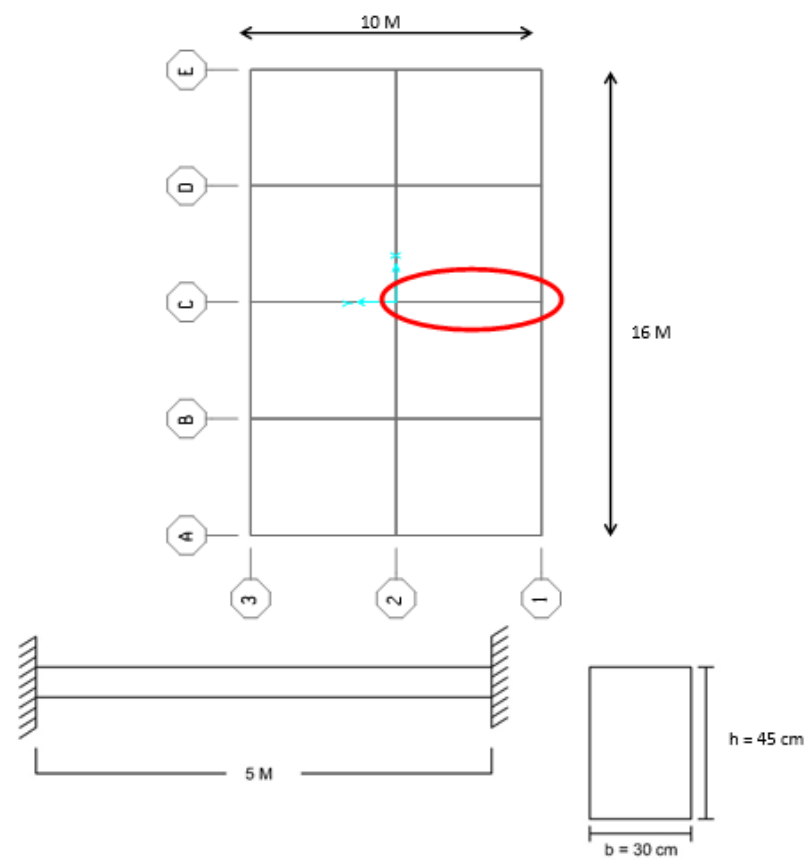

Gambar 4. Denah Penelitian

\section{Skema Penelitian}

Sumber: Data Olahan, 2020

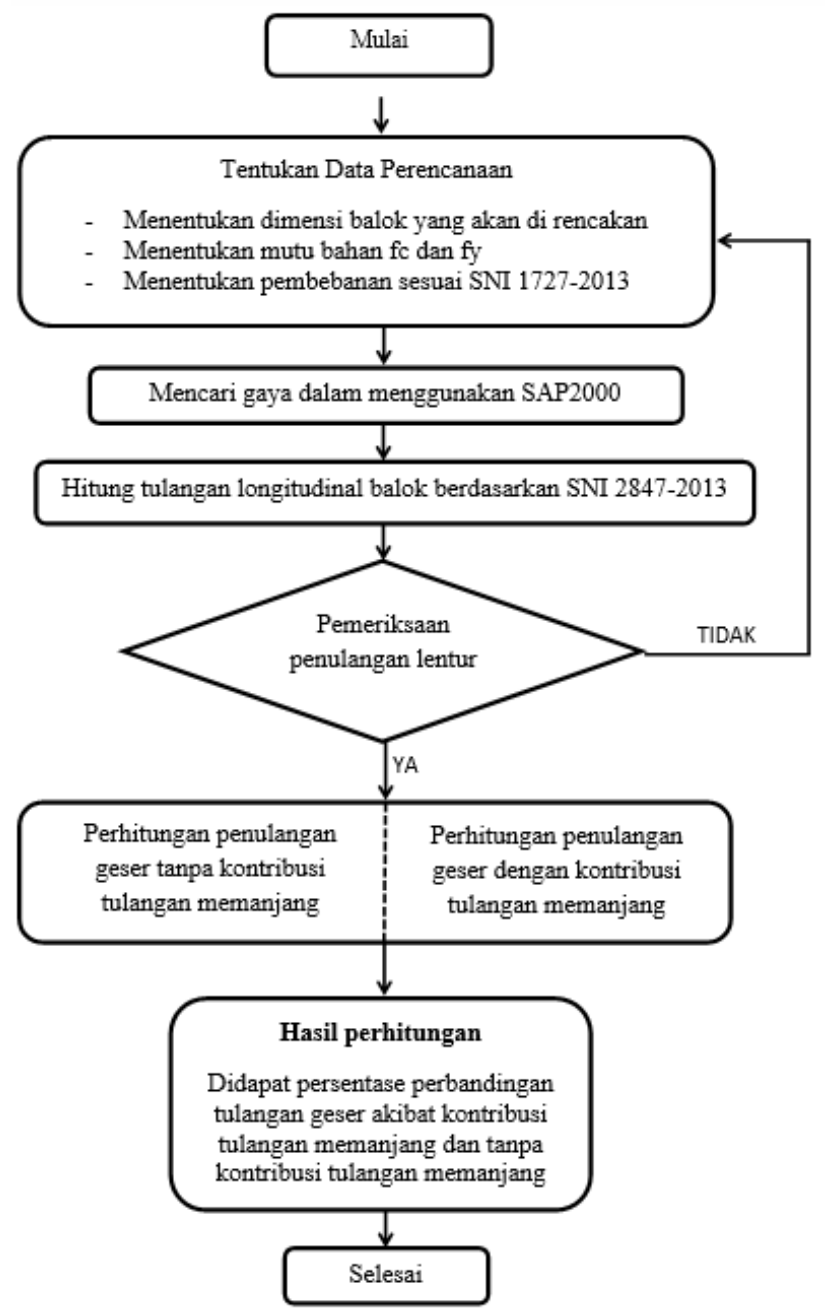

Gambar 5. Flow Chart Penelitian 
Al Fauzi Afendi, Azwarman dan Ria Zulfiati, Kontribusi Tulangan Memanjang Terhadap Kekuatan Geser Pada Penampang Balok Beton

\section{HASIL DAN PEMBAHASAN}

Pada penelitian ini menggunakan contoh perhitungan kekuatan geser $\mathrm{V}_{\mathrm{c}}$ yang disumbangkan oleh beton dan tulangan memanjang/longitudinal pada balok yang ditinjau di perencanaan rangka gedung lantai 4 yang diketahui sebagai berikut.

Dimensi:

- Balok 300x450 mm

- Kolom 400x400 mm

Mutu Bahan:

- $\mathrm{f}_{\mathrm{c}}=20 \mathrm{MPa} \quad$ (Kuat Tekan Beton)

- $\mathrm{f}_{\mathrm{y}}=400 \mathrm{MPa}$ (Tegangan Leleh Baja Tulangan Memanjang)

- $\mathrm{f}_{\mathrm{yt}}=240 \mathrm{MPa}$ (Tegangan Leleh Baja Tulangan Geser)

Pembebanan:
Beban mati pelat lantai

$$
\begin{aligned}
& =4,48 \mathrm{KN} \cdot \mathrm{m}^{2} \\
& =2,9 \mathrm{KN} \cdot \mathrm{m}^{2}
\end{aligned}
$$

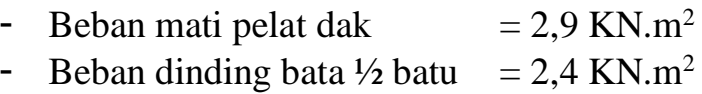
- Beban hidup lantai $1 \mathrm{~s} / \mathrm{d} 3=2,5 \mathrm{KN} \cdot \mathrm{m}^{2}$
- Beban hidup atap $\quad=1 \mathrm{KN} \cdot \mathrm{m}^{2}$

Hasil perhitungan gaya dalam menggunakan SAP2000 didapat moment terbesar pada balok di lantai 1, untuk gaya geser tumpuan sebelah kiri sebesar 76, $88 \mathrm{KN}$ dan gaya geser sebelah kanan sebesar 69,12 KN.

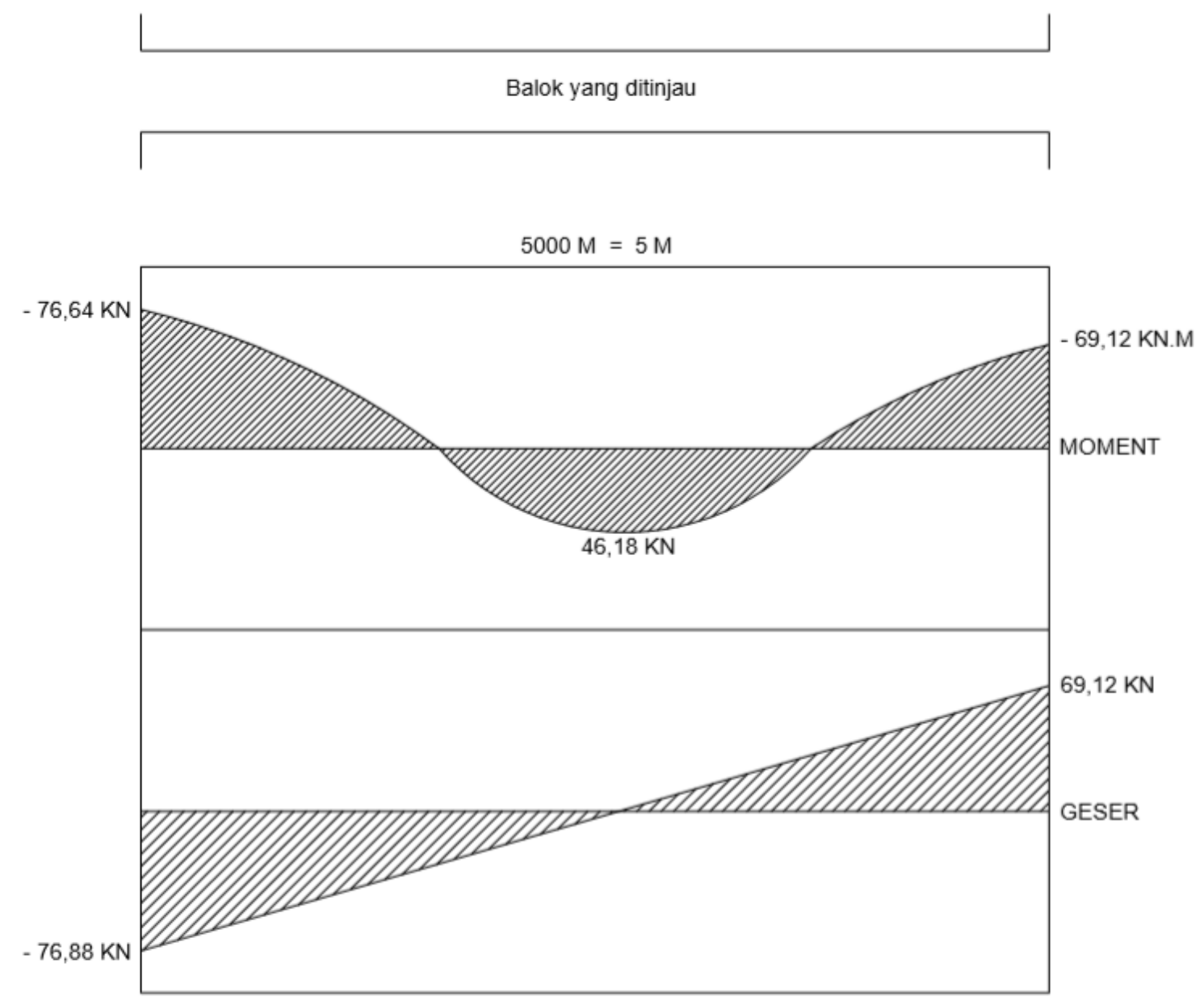

Sumber: Data Olahan, 2020

Gambar 6. Hasil perhitungan gaya moment dan geser menggunakan SAP2000 


\section{Jumlah Penulangan Geser Tanpa Kontribusi Tulangan Memanjang}
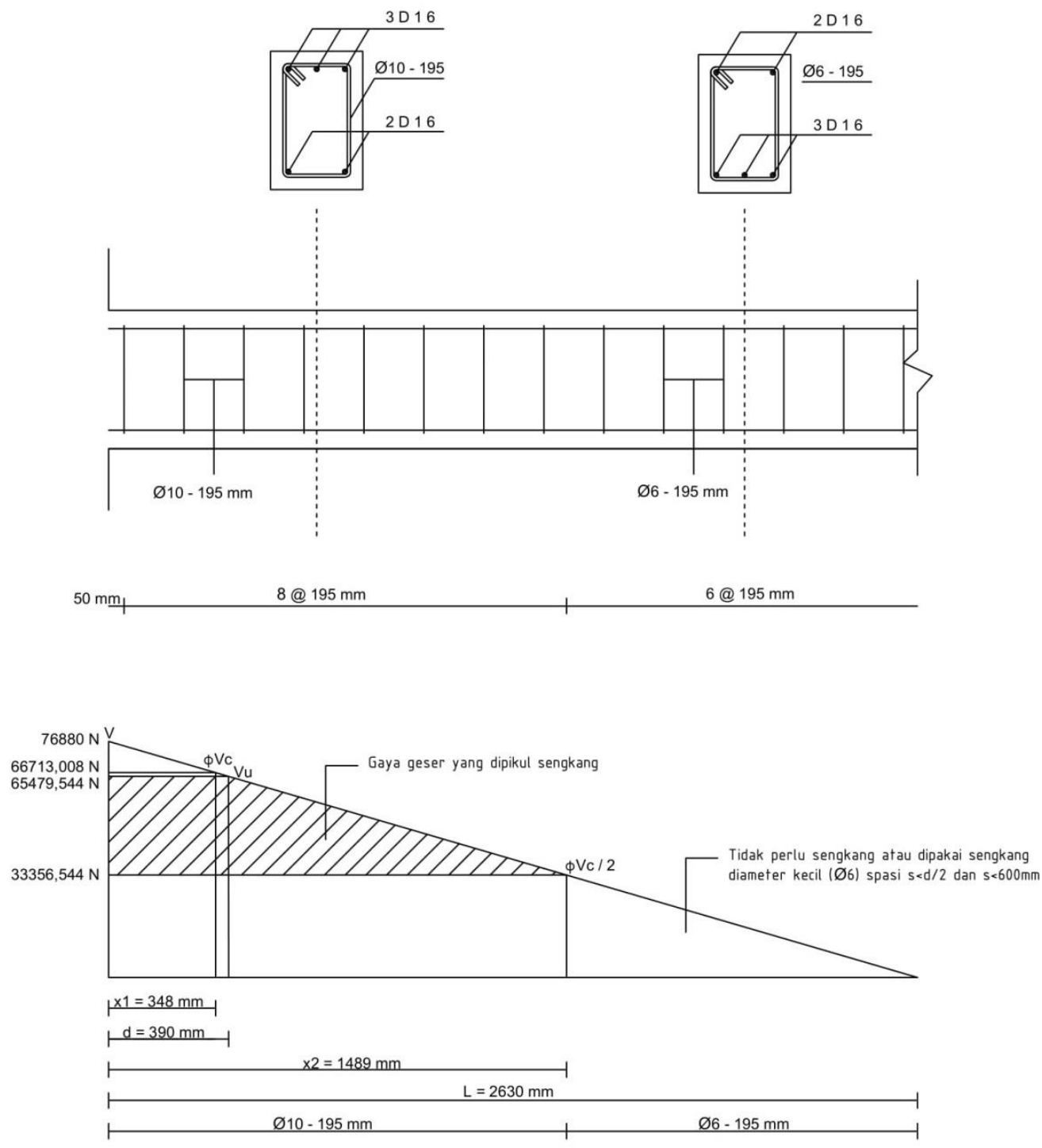

Sumber: Data Olahan, 2020

Gambar 7. Hasil perhitungan penulangan memanjang dan geser

Tulangan Sengkang/begel dapat didistribusikan sebagai berikut :

1. Sengkang pertama dipasang sejarak $195 / 2=97,5 \rightarrow 50 \mathrm{~mm}$ di muka tumpuan

2. Sengkang berikutnya dipasang sejarak 195 dari muka tumpuan, total sengkang terpasang pada setengah bentang balok untuk $\varnothing 10$ sebanyak 8 buah dan $\varnothing 6$ sebanyak 6 buah

3. Sehingga total sengkang yang dibutuhkan untuk sepanjang balok adalah : Ø10 sebanyak 16 buah dan $\emptyset 6$ sebanyak 12 buah 


\section{Jumlah Penulangan Geser Dengan Kontribusi Tulangan Memanjang}
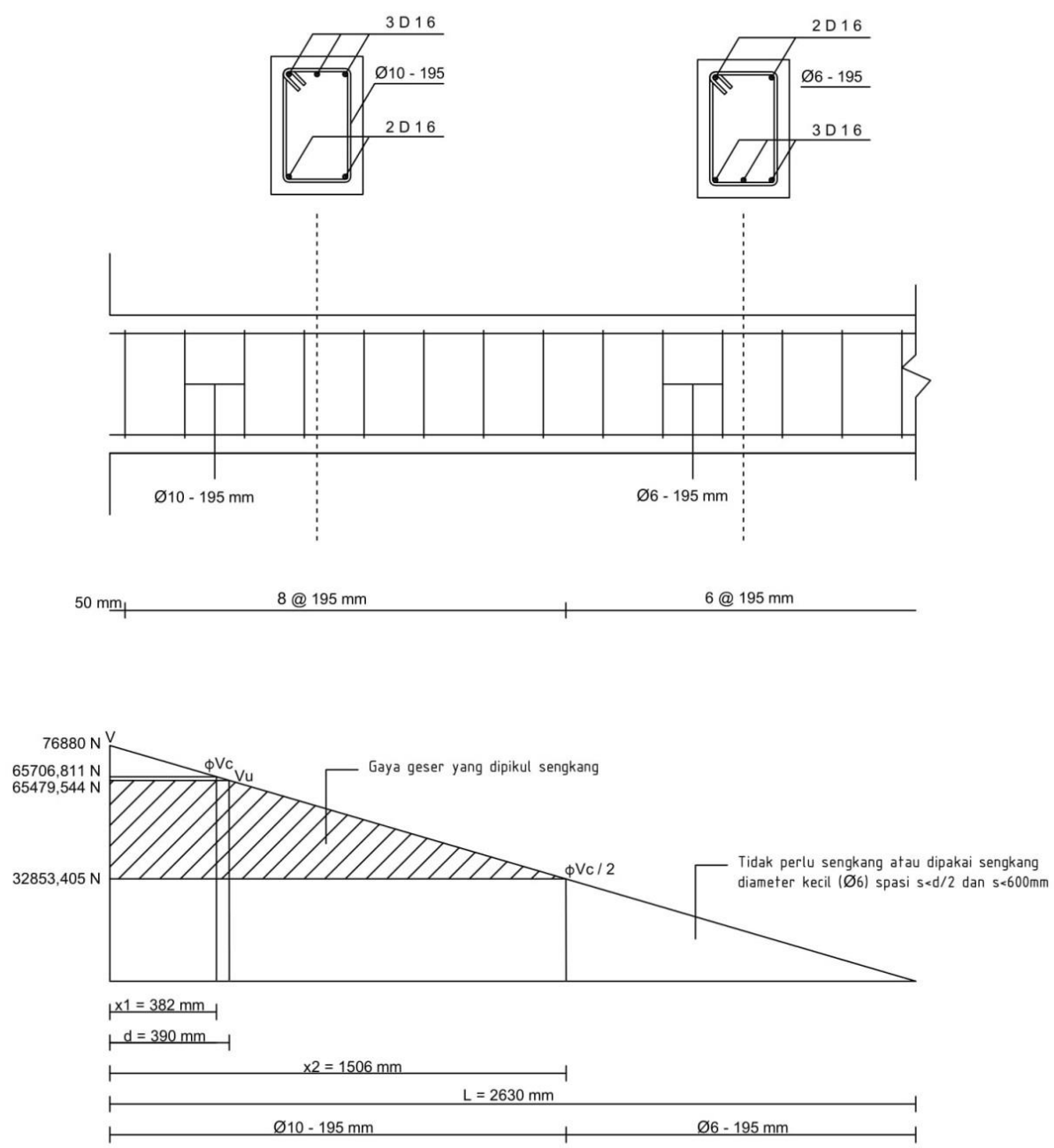

Sumber: Data Olahan, 2020

Gambar 8. Hasil perhitungan penulangan memanjang dan geser

Tulangan Sengkang/begel dapat didistribusikan sebagai berikut :

1. Sengkang pertama dipasang sejarak $195 / 2=97,5 \rightarrow 50 \mathrm{~mm}$ di muka tumpuan

2. Sengkang berikutnya dipasang sejarak 195 dari muka tumpuan, total sengkang terpasang pada setengah bentang balok untuk $\varnothing 10$ sebanyak 8 buah dan $\emptyset 6$ sebanyak 6 buah

3. Sehingga total sengkang yang dibutuhkan untuk sepanjang balok adalah : Ø10 sebanyak 16 buah dan $\emptyset 6$ sebanyak 12 buah

\section{SIMPULAN}

Dari hasil analisa perhitungan menggunakan contoh perhitungan balok yang ditinjau dari rangka bangunan gedung lantai 4 yang diketahui beban mati dan beban hidup. Bahwa kontribusi tulangan memanjang pada balok beton yang ditinjau dapat disimpulkan :

1. Pada contoh perhitungan balok yang ditinjau dari rangka bangunan gedung lantai 4 dengan berdasarkan SNI 28472013 ternyata dengan adanya kontribusi tulangan memanjang hasil yang didapatkan hampir sama atau sama dengan tanpa adanya kontribusi tulangan memanjang, dimana dengan adanya kontribusi tulangan memanjang didapat sengkang/begel sebanyak 8 buah untuk besi $\varnothing 10$ dan 6 buah untuk besi $\varnothing 6$, sedangkan perhitungkan tanpa adanya kontribusi tulangan memanjang didapat sengkang/begel yang sama yaitu sebanyak 8 buah besi $\emptyset 10$ dan 6 buah untuk besi $\varnothing 6$.

2. Nilai $\rho$ adalah rasio tulangan memanjang/longitudinal, dengan adanya rasio $\rho$ pada perhitungan penulangan geser tidak begitu mempengaruhi luas geser penampang.

3. Perkembangan SNI 2847-2013 tentang persyaratan beton struktural untuk bangunan gedung, dimana untuk tingkat ketelitiannya sangat akurat sekali dibandingkan dengan SNI sebelum-sebelumnya. 
Al Fauzi Afendi, Azwarman dan Ria Zulfiati, Kontribusi Tulangan Memanjang Terhadap Kekuatan Geser Pada Penampang Balok Beton

\section{DAFTAR PUSTAKA}

Agus Setiawan, 2016. Perancangan Struktur Beton Bertulang Berdasarkan SNI 2847:2013, Erlangga, Jakarta. Ali Asroni, 2017. Teori dan Desain Balok Plat Beton Bertulang Berdasaarkan SNI 2847:2013, MUP, Surakarta SNI-03-2847-2013, 2013.Tata Cara Perhitungan Struktur Beton Untuk Bangunan Gedung, Bandung.

SNI 1727:2013, 2013.Beban Minimum Untuk Prencangan Bangunan Gedung dan Struktur Lain, Jakarta. MacCormac, J.C, 2001. Desain Beton Bertulang, Erlangga, Jakarta

Vis, W.C, 1993. Dasar-dasar Perencanaan Beton Bertulang, Erlangga, Jakarta 